\title{
Relaçôes jurídicas transnacionais em tempos de COVID-19
}

https://doi.org/10.21814/uminho.ed.25.15

\section{Anabela Susana de Sousa Gonçalves}

Anabela Susana de Sousa Gonçalves (ORCID: 0000-0001-6140-1711) é Professora Associada da Escola de Direito da Universidade do Minho, sendo atualmente Vice-Presidente da Escola. É investigadora do JusGov - Centro de Investigação em Justiça e Governação. É perita da Comissão Europeia para avaliação de projetos no âmbito do programa JUSTICE e membro do European Research Council, por nomeação da Comissão Europeia. 


\section{RELAÇÕES JURÍDICAS TRANSNACIONAIS}

Vivemos num mundo globalizado, em que pessoas e empresas facilmente estabelecem relações jurídicas transnacionais: as pessoas quando viajam; quando estão em teletrabalho para uma empresa com sede ou estabelecimento em outro país; quando prestam ou contratam serviços noutros países; quando fazem compras na internet, celebrando contratos de consumo internacionais; quando aderem e usam a redes sociais com sede ou estabelecimento em outros países, entre outras; as empresas quando celebram contratos com empresas com sede ou estabelecimentos noutros países; ou com consumidores com residência habitual noutros países; quando prestam serviços no mercado internacional; quando colocam os seus trabalhadores em teletrabalho, podendo estes estar dispersos por qualquer lugar do mundo; quando usam a internet como meio de negócio, uma vez que esta, pelas suas características, tem uma natureza deslocalizada, podendo os seus utilizadores estar dispersos por todo o mundo. Estes são alguns exemplos, mas poderíamos elencar muitos outros.

As relações jurídicas transnacionais, também designadas por relações jurídicas privadas internacionais, ou situações heterogéneas, ou plurilocalizadas, são aquelas que têm elementos de estraneidade, ou seja, são aquelas cujos elementos constitutivos estão em ligação com mais do que uma ordem jurídica ${ }^{1}$. Isabel de Magalhães Collaço considera que o aspeto que diferencia as relaçôes privadas internacionais é o facto de

\footnotetext{
1 E que por essa razão são objeto do Direito Internacional Privado (DIP). Sobre o objeto do DIP, entre outros, Collaço, Isabel de Magalhães (1966). Direito Internacional Privado, Vol. I (pp 13 e segs). Lisboa: AAFDL; Correia, António Ferrer (1984). Direito Internacional Privado. In: Roque Cabral, Mário Bigotte Chorão et al. (1984), Polis, Enciclopédia Verbo do Direito e do Estado, Vol. II (p. 461). Lisboa: Verbo; Correia, António Ferrer (2007). Liçôes de Direito Internacional Privado I, 4a Reimpressão da edição de 2000 (pp. 11 e segs). Coimbra: Almedina; Machado, João Baptista (1997). Liçôes de Direito Internacional Privado, 3 a Edição, Reimpressão (pp 12-13). Coimbra: Almedina; Pinheiro, Luís de Lima (2008). Direito Internacional Privado, Introduçãoe Direito de Conflitos, Parte Geral, Vol. I, 2a Ed. Refundida (pp. 37-40). Coimbra: Almedina; Santos, António Marques dos (1999). Direito Internacional Privado, Sumários, Reimpressão (pp. 3-7). Lisboa: AAFDL; Santos, António Marques dos (2001). Direito Internacional Privado. In José Pedro Fernandes (Ed.), Dicionário da Administração Pública, 2o suplemento (pp. 263 e segs. Lisboa: Almedina; Santos, António Marques dos (2001). Direito Internacional Privado, Introdução, Vol. I (pp. 7 e segs). Lisboa: AAFDL.
} 
serem «(...) relaçóes “atravessadas por fronteiras” $(\ldots) »^{2}$. Da nossa parte, preferimos dizer que são relações jurídicas que atravessam fronteiras, quer em sede de constituição (relaçôes absolutamente internacionais, que estão desde o momento da sua formação em contacto com mais do que uma ordem jurídica), quer em sede de reconhecimento (relações relativamente internacionais, que têm no momento da sua constituição um caráter puramente interno, entrando posteriormente em contacto com outra ordem jurídica, quando há a necessidade de aí as reconhecer).

Este mundo globalizado é intuitivo para cada um de nós e facilmente nos envolvemos em relaçôes jurídicas privadas transnacionais, mas o vírus SARS-CoV-2 alterou a nossa normalidade e fez-nos viver uma realidade que a maioria de nós nunca pensou ser possível. Fechou-nos em casa e obrigou os Estados a encerrar fronteiras, a fechar-se sobre si mesmos. Transformou a nossa vivência social e forçou os Estados a elaborar um conjunto de legislação especial, que garantisse o distanciamento social, quer apoiando os trabalhadores em geral e, especificamente na área da saúde e outras áreas consideradas essenciais, dinamizando o teletrabalho, encerrando atividades, alterando o funcionamento de serviços públicos e de outras áreas de atividade. Entre outras medidas, em Portugal, foram estabelecidas medidas de apoio aos trabalhadores ${ }^{3}$; medidas que

2 Collaço, Isabel de Magalhães (1966). Direito Internacional Privado, Vol. I (pp 16 e segs). Lisboa: AAFDL. 3 A título de exemplo podemos indicar: o Decreto-Lei no 10-A/2020, de 13 de março, que estabeleceu medidas excecionais e temporárias relativas à situação epidemiológica do novo Coronavírus - COVID-19, e o Decreto-Lei no 10-K/2020 (Diário da República № 61/2020, 1o Suplemento, Série I de 2020-03-26), que estabeleceu um regime excecional e temporário de faltas justificadas motivadas por assistência à família, no âmbito da pandemia da doença COVID-19; a Portaria no 82/2020 (Diário da República no 62-B/2020, Série I de 29 de março de 2020), que estabeleceu os serviços essenciais para efeitos de acolhimento, nos estabelecimentos de ensino, dos filhos ou outros dependentes a cargo dos respetivos profissionais, de acordo com o no 1 do artigo 10o do Decreto-Lei no 10-A/2020, de 13 de março, que estabelece medidas excecionais e temporárias relativas à situação epidemiológica do novo Coronavírus - COVID-19; o Despacho no 3301/2020 (Diário da República no 52-B/2020, Série II de 2020-03-15) que estabeleceu as regras em matéria de articulação entre a assistência à família e a disponibilidade para a prestação de cuidados, como forma de garantir a continuidade da resposta do Serviço Nacional de Saúde (SNS) e cuja vigência foi prolongada pelo Despacho no 4396/2020 (Diário da República no 71-A/2020, Série II de 2020-04-10). 


\section{alteraram o funcionamento de serviços públicos ${ }^{4} \mathrm{e}$ da Justiça $a^{5}$; foram suspensas as ações} de despejo $^{6}$; foram estabelecidas medidas de proteção de créditos de famílias e empresas $^{7}$; foram tomadas medidas de proteção dos postos de trabalho ${ }^{8}$.

A COVID-19 teve repercussões nas relações jurídicas internas, mas também nas relaçốes internacionais, não só na vertente de relações entre os Estados, mas também na vertente entre sujeitos privados ou entre entes privados e Estados, podendo estes com

4 A título de exemplo podemos indicar: o Despacho no 3614-C/2020 (Diário da República no 58/2020, 10 Suplemento, Série II de 2020-03-23), que determinou os termos do funcionamento de serviços junto da Direção-Geral de Reinserção e Serviços Prisionais, da Polícia Judiciária, do Instituto Nacional de Medicina Legal e Ciências Forenses, I. P., e do Instituto dos Registos e Notariado, I. P., durante o estado de emergência; a Lei no 1-A/2020 (Diário da República no 56/2020, 3o Suplemento, Série I de 2020-03-19), que estabeleceu medidas excecionais e temporárias de resposta à situação epidemiológica provocada pelo coronavírus SARS-CoV-2 e da doença COVID-19, alterada pela Lei no 4-A/2020, de 6 de abril.

$5 \mathrm{O}$ art. 6o do Regime do Estado de Sítio e do Estado de Emergência estabelece que na vigência do estado de emergência, os cidadãos mantêm, em pleno, o direito de acesso aos tribunais, para defesa dos seus direitos, liberdades e garantias lesados ou ameaçados de lesão por quaisquer providências inconstitucionais ou ilegais. De acordo com o art. 14o Decreto-Lei no 10-A/2020 foi considerado um justo impedimento à prática de atos processuais e procedimentais, que devam ser praticados presencialmente, a declaração emitida por autoridade de saúde a favor de sujeito processual, parte, seus representantes ou mandatários, que ateste a necessidade de um período de isolamento destes por eventual risco de contágio da COVID-19. Esta declaração também podia ser justificação para não comparecimento em qualquer diligência processual ou procedimental, bem como do seu adiamento, no âmbito de processo. Nos termos do art. 15으, do mesmo diploma, se as instalações onde os atos processuais devessem ser praticados fossem encerradas por decisão de autoridade pública com fundamento no risco de contágio da COVID-19, considerava-se suspenso o prazo para a prática de atos processuais a partir do dia do encerramento ou da suspensão do atendimento. Segundo o art. 7o, no 1, da Lei no 1-A/2020, os prazos para a prática de atos processuais e procedimentais que deviam ser praticados no âmbito dos processos e procedimentos que corriam termos nos tribunais e entidades de resolução alternativa de litígios ficaram suspensos até à cessação da situação excecional de prevenção, contenção, mitigação e tratamento da infeção epidemiológica por SARS-CoV-2 e da doença COVID-19. Também se suspenderam os prazos de prescrição e de caducidade relativos a todos os tipos de processos e procedimentos (art. 7o, no 3). Ficaram suspensos, por exemplo, os prazos de apresentação do devedor à insolvência ou quaisquer atos a realizar em sede de processo executivo (art. 7o, no 6). Ainda assim, o art. 5ํ, no 5, permitia: a tramitação dos processos e a prática de atos presenciais e não presenciais não urgentes, quando todas as partes entendiam ter condiçốes para assegurar a sua prática através das plataformas informáticas que possibilitavam a sua realização por via eletrónica ou através de meios de comunicação à distância adequados, designadamente teleconferência, videochamada ou outro equivalente; que fosse proferida decisão final nos processos em que não sejam precisos novas diligências. Garantindo-se o recurso aos meios de comunicação à distância, os processos urgentes continuaram a ser tramitados, sem suspensão ou interrupção de prazos, atos ou diligências, nos termos do art. 7o, no 7, da Lei no 1-A/2020.

6 Pela Lei no 1-A/2020 (Diário da República no 56/2020, 3 Suplemento, Série I de 2020-03-19), que estabeleceu medidas excecionais e temporárias de resposta à situação epidemiológica provocada pelo coronavírus SARS-CoV-2 e da doença COVID-19, alterada pela Lei no 4-A/2020, de 6 de abril. Esta determinava no art. 7o , o 11, que durante o período excecional de emergência, eram suspensas as ações de despejo, os procedimentos especiais de despejo e os processos para entrega de coisa imóvel arrendada, quando o arrendatário, por força da decisão judicial final a proferir, pudesse ser colocado em situação de fragilidade por falta de habitação própria ou por outra razão social imperiosa. Também a Lei no 4-C/2020 (Diário da República no 68/2020, 3올emento, Série I DE 2020-04-06) fixou um regime excecional para as situações de mora no pagamento da renda devida nos termos de contratos de arrendamento urbano habitacional e não habitacional, no âmbito da pandemia COVID-19.

7 O Decreto-Lei no 10-J/2020 (Diário da República no 61/2020, 1o Suplemento, Série I de 2020- 03-26, alterado pela Lei no 8/2020 publicada no Diário da República no 71-A/2020, Série I DE 2020- 04-10) que estabelece medidas excecionais de proteção dos créditos das famílias, empresas, instituiçôes particulares de solidariedade social e demais entidades da economia social, bem como um regime especial de garantias pessoais do Estado, no âmbito da pandemia da doença COVID-19.

8 Através do Decreto-Lei no 10-G/2020 (Diário da República no 61/2020, 1o Suplemento, Série I de 2020-03-26) que estabeleceu uma medida excecional e temporária de proteção dos postos de trabalho, no âmbito da pandemia COVID-19 e do Despacho no 2875-A/2020 (Diário da República no 44/2020, 1o Suplemento, Série II de 2020-03-03 que adotou medidas para acautelar a proteção social dos beneficiários que se encontrassem impedidos, temporariamente, do exercício da sua atividade profissional por ordem da autoridade de saúde, devido a perigo de contágio pela COVID-19. 
ou despidos do seu poder de ius imperii. O que pretendemos brevemente analisar é a influência da COVID-19 sobre algumas destas relaçôes jurídicas transnacionais.

\section{A RESPONSABILIDADE CIVIL EXTRACONTRATUAL POR DANOS RESULTANTES DA COVID-19}

As repercussões económicas e sociais da COVID-19 são enormes e os danos integrais ainda estão por apurar. Ainda que neste momento estes danos sejam difíceis de quantificar, certamente não exageramos ao afirmar que, entre os recursos empregues nos sistemas nacionais de saúde, empregos perdidos e negócios frustrados, aqueles poderão ascender a milhões de euros.

Uma das questóes mais debatidas no plano político é a responsabilidade da República da China pelo surgimento e propagação mundial do vírus. De facto, vários líderes mundiais têm criticado a forma como a China geriu o início da pandemia e/ou as informações que foi dando à Organização Mundial de Saúde (OMS) e aos outros países ${ }^{9}$. Outros foram mais longe e afirmaram que a China deveria pagar os danos resultantes da disseminação mundial dos vírus, exigindo uma investigação internacional sobre a sua origem ${ }^{10}$. Além dos danos políticos que estas acusações podem provocar ${ }^{11}$, cabe-nos perguntar se no plano jurídico é possível acionar a China por danos resultantes da propagação mundial do vírus.

9 É o caso do presidente francês Emmanuel Macron, na entrevista que deu ao Financial Times: https://www. ft.com/content/3ea8d790-7fd1-11ea-8fdb-7ec06edeef84, em 01.06.2020.

10 Foi o caso do primeiro-ministro australiano George Christensen: https://www.cmjornal.pt/mundo/detalhe/china-devia-pagar-pela-propagacao-global-do-coronavirus-ministro-australiano-diz-que-virus-foi-criado-em-laboratorio, em 01.06.2020; https://sol.sapo.pt/artigo/694800/apesar-das-ameacas-da-china-australia-promete-investigar-origem-do-coronavirus-, em 01.06.2020; do presidente norte-americano Donald Trump: https://sicnoticias.pt/especiais/coronavirus/2020-05-20-COVID-19-Trump-responsabiliza-incompetencia-da-China-por-mortes-no-mundo, em 01.06.2020; do governo do Reino Unido: https://brasil.elpais. com/internacional/2020-04-21/franca-e-reino-unido-lideram-endurecimento-do-tom-europeu-com-a-china. html, em 01.02.2020, https://rr.sapo.pt/2020/04/16/mundo/COVID-19-reino-unido-diz-que-china-deve-esclarecer-origem-do-virus/noticia/189556/, em 01.02.2020.

11 Há notícias de ameaças de quebra de relações bilaterais entre os EUA e a China: https://tvi24.iol.pt/ internacional/coronavirus/COVID-19-donald-trump-ameaca-cortar-relacoes-com-a-china, em 01.06.2020. 
Uma eventual ação civil teria que ter por fundamento a responsabilidade civil extracontratual. Na responsabilidade civil extracontratual estamos perante factos que constituem violaçóes de direitos absolutos de outrem ou de interesses legalmente protegidos, dando origem a uma obrigação de indemnizar por força de uma imposição legal. Desta forma, nasce uma obrigação baseada na lei, que se diferencia daquelas que têm como fonte a vontade das partes e que dão origem à responsabilidade contratual ${ }^{12}$. A obrigação de indemnizar que resulta da responsabilidade civil extracontratual visa a transferência dos danos da pessoa que os sofreu para a pessoa que agiu ou deveria ter agido, numa perspetiva de distribuição dos danos. No caso, estaria em causa uma situação de responsabilidade civil extracontratual em situaçôes transnacionais, por violação do direito à saúde $\mathrm{e}^{13}$, do qual resultaram danos não patrimoniais e danos patrimoniais ${ }^{14}$. A primeira questão consistiria, então, em saber se seria possível propor uma ação de responsabilidade civil extracontratual contra a China por danos ocorridos em Portugal em resultado da COVID-19.

12 V. sobre a distinção entre responsabilidade civil extracontratual e a responsabilidade civil, Alarcão, Rui de (1983). Direito das Obrigações, texto elaborado pelos Drs. J. Sousa Ribeiro, J. Sinde Monteiro, Almeno de Sá, J. C. Proença, com base nas liçốes do Prof. Doutor Rui de Alarcão ao 3o Ano Jurídico (pp. 174-175). Coimbra; Andrade, Manuel A. Domingues de (2003). Teoria Geral da Relação Jurídica, Sujeitos e Objecto, Vol. I (p. 127). Coimbra: Almedina; Cordeiro, António Menezes (2010). Direito Civil Português II, Direito das Obrigaçôes, t. III (pp. 285 e segs). Coimbra: Almedina; Costa, Mário Júlio de Almeida (2001). Noçôes Fundamentais de Direito Civil, 4a Ed. revista e actualizada com a colaboração de Henrique Sousa Antunes (pp. 103-105). Coimbra: Almedina; Costa, Mário Júlio de Almeida (2009). Direito das Obrigaçôes, 12a Ed. Revista e actualizada (pp. 539 e segs). Coimbra: Almedina; Hörster. Heinrich Ewald (2007). A Parte Geral do Código Civil Português, Teoria Geral do Direito Civil, 4a Reimpressão da edição de 1992 (p. 70 e segs). Coimbra: Almedina; Hörster. Heinrich Ewald (2004). Esboço esquemático sobre a responsabilidade civil de acordo com as regras do Código Civil. In Estudos em Comemoração do 10 o Aniversário da Licenciatura em Direito da Universidade do Minho (pp. 326 e segs). Coimbra: Almedina; Leitão, Luís Manuel Teles de Menezes (2010). Direito das Obrigações, Introdução, Da Constituição das Obrigações, Vol. I, 9ạ Ed. (pp. 291 e segs). Coimbra: Almedina; Martinez, Pedro Romano (2004). Direito das Obrigaçóes, Apontamentos, com a colaboração de Pedro Múrias e Pedro Paes de Vasconcelos, 2a Ed. (pp. 83 e segs). Lisboa: AAFDL. Referindo a superação da divisão tradicional entre responsabilidade contratual e extracontratual: Martinez, Pedro Romano (2004). Direito das Obrigaçães, Apontamentos, com a colaboração de Pedro Múrias e Pedro Paes de Vasconcelos, 2a Ed. (pp. 86 e segs). Lisboa: AAFDL; Pinto, Carlos Alberto da Mota (1994). Teoria Geral do Direito Civil, 3르. Ed. actualizada, (p. 123). Coimbra: Coimbra Editora; Santos Júnior, E. (2003). Da Responsabilidade Civil de Terceiro por Lesão do Direito de Crédito (pp. 203 e segs). Coimbra: Almedina; Telles, Inocêncio Galvão (1989). Direito das Obrigaçốes, 7a Ed. revista e actualizada (pp. 211 e segs). Coimbra: Coimbra Editora.

13 Que é um direito de personalidade, um direito absoluto, cujo regime jurídico se encontra previsto no Código Civil (C.C.) português a partir do art. 70o. Para mais desenvolvimentos, v. Ascensão, José de Oliveira (2002). Direito Civil Teoria Geral, Relaçôes e Situaçôes Jurídicas, Vol. III (pp. 94-97). Coimbra: Coimbra Editora; Vasconcelos, Pedro Pais de (2012). Teoria Geral do Direito Civil, 7a ed. (pp. 43-76). Coimbra: Almedina; Hörster. Heinrich Ewald (2007). A Parte Geral do Código Civil Português, Teoria Geral do Direito Civil, 4ª Reimpressão da edição de 1992 (257-271). Coimbra: Almedina.

$14 \mathrm{Ou}$ seja, os prejuízos não suscetíveis de avaliação pecuniária e aqueles suscetíveis de avaliação pecuniária. Sobre esta distinção, v. Leitão, Luís Manuel Teles de Menezes (2010). Direito das Obrigações, Introdução, Da Constituição das Obrigaçôes, Vol. I, 9a Ed. (pp. 332-335). Coimbra: Almedina; Varela, João de Matos Antunes (2000). Das Obrigaçốes em Geral, Vol. I, 10르. Ed. (597-602). Coimbra: Almedina. 
Há duas questôes prévias que poderiam sustentar uma ação de responsabilidade civil que não são de fácil resolução. A primeira, é a prova do envolvimento da China no surgimento do vírus. Não há qualquer dado científico comprovado do envolvimento do governo chinês no surgimento do vírus. Há uma teoria que sustenta que o vírus foi criado artificialmente ou escapou do Instituto de Virologia de Whuan, mas sem comprovação científica. Como têm defendido alguns autores, a ligação da China ao surgimento do vírus só poderia ser estabelecida por uma comissão internacional e independente de peritos, sob a égide eventualmente das Naçóes Unidas ou da OMS, mas realisticamente nada obriga a China a aceitar esta solução de uma comissão independente e a colaborar com a investigação da mesma ${ }^{15}$. A segunda, seria a eventual negligência da China na contenção do vírus e a eventual retenção de informação sobre a perigosidade e elevado grau de contágio do mesmo $^{16}$. Mais uma vez, também neste caso a prova teria de ser obtida na China, através de uma comissão internacional e independente de peritos, com todas as dificuldades que já referimos.

Partamos, todavia, do princípio que a referida prova, em qualquer uma das duas situaçóes pode ser feita, novamente, duas hipóteses têm sido levantadas pela doutrina internacional.

Na primeira hipótese, conseguia-se provar que o vírus foi criado como uma arma bacteriológica pela China. Neste caso, certos autores avançam que estaria em causa a violação da Convenção sobre a Proibição do Desenvolvimento, Produção e Armazenamento de Armas Bacteriológicas (Biológicas) e Toxinas e sobre sua Destruição de 10 de abril de 1972, da qual a China é parte desde $1984^{17}$. Neste caso, o art. VI da referida Convenção estabelece que qualquer Estado parte na Convenção (da qual são parte 183 Estados) pode apresentar uma queixa ao Conselho de Segurança das Nações Unidas, apresentando provas. Nada é referido na Convenção sobre eventuais sanções para os

15 Neste sentido Fabrizio Marrella: https://www.unive.it/pag/14024/?tx_news_pi1\%5Bnews\%5D=8888\&cHash=c7da097dd264181780fba70ae15d81a6, em 01.06.2020; Javier Carrascosa González no seu blog: http://accursio.com/blog/?p=1099, em 01.06.2020.

16 Neste sentido Javier Carrascosa González: http://accursio.com/blog/?p=1099, em 01.06.2020.

17 Fabrizio Marrella: https://www.unive.it/pag/14024/?tx_news_pi1\%5Bnews\%5D=8888\&cHash=c7da097dd264181780fba70ae15d81a6, em 01.06.2020; Javier Carrascosa González no seu blog: http://accursio. com/blog/?p=1099, em 01.06.2020. 
Estados não cumpridores. Nesta hipótese, pode-se sempre colocar o cenário de um Estado acionar a China perante um Tribunal Internacional, não sendo claro qual o tribunal que poderia julgar esta questão ${ }^{18}$.

$\mathrm{Na}$ segunda hipótese, prova-se o envolvimento do China na criação do vírus ou a sua negligência em conter o vírus ou violação de um dever de informação sobre a perigosidade do vírus e uma pessoa singular ou um grupo de cidadãos coloca uma ação coletiva em tribunal português para ressarcimento de danos. Note-se que esta hipótese não é tão descabida pois assistimos noutros países a açóes propostas por cidadãos contra a China. No Brasil, há notícias de uma ação coletiva proposta pela Associação Comercial de Cabo Frio-RJ contra a China pedindo uma indemnização por prejuízos à atividade comercial ${ }^{19}$. Também nos EUA, há notícias de uma ação de indemnização proposta contra a China por danos decorrentes da má gestão que a China do vírus e pela ocultação de informações sobre a gravidade do mesmo ${ }^{20}$.

A primeira questão a responder é determinar se os tribunais portugueses teriam competência internacional para julgar estas ações. O Regulamento no 1215/2012 do Parlamento Europeu e do Conselho de 12 de dezembro de 2012 relativo à competência judiciária, ao reconhecimento è execução de decisóes em matéria civil e comercial (Bruxelas I bis) não se aplicaria ao caso, porque as regras de jurisdição presentes no regulamento Bruxelas I bis apenas são aplicadas quando o requerido tem domićlio num Estado-Membro (art. 4º). Caso contrário, serão aplicáveis as regras de competência nacionais dos Estados-Membros, ressalvando-se as situações elencadas no art. 6o, ํo $1^{21}$. Por isso,

18 Como apontam os referidos autores: Fabrizio Marrella: https://www.unive.it/pag/14024/?tx_news pi1\%5Bnews\%5D=8888\&cHash=c7da097dd264181780fba70ae15d81a6, em 01.06.2020; Javier Carrascosa González no seu blog: http://accursio.com/blog/?p=1099, em 01.06.2020.

19https://www.em.com.br/app/noticia/economia/mf-press/2020/04/20/mf press economia economia,1140555/acao-civil-publica-contra-a-china-pede-r-420-bilhoes-de-indenizacao-e.shtml, em 01.06.2020.

20https://www.dn.pt/mundo/missouri-nos-eua-processa-china-e-pede-milhoes-pela-ma-gestao-do-virus-12101225.html, 01.06.2020.

21 Para mais desenvolvimentos sobre este Regulamento, v. Gonçalves, Anabela Susana de Sousa (2014). A revisão do regulamento Bruxelas I relativo à competência judiciária, ao reconhecimento e à execução de decisões em matéria civil e comercial. In Estudos em Comemoração dos 20 Anos da Escola de Direito (pp. 39-59). Coimbra: Coimbra Editora. 
seria necessário recorrer às regras de competência previstas no Código de Processo Civil (CPC). No âmbito do CPC, os tribunais portugueses poderiam ser competentes de acordo com a al. c) do art. 62, 2a parte, do CPC: «(...) quando o direito invocado não possa tornar-se efetivo senão por meio de ação proposta em território português ou se verifique para o autor dificuldade apreciável na propositura da ação no estrangeiro, desde que entre o objeto do litígio e a ordem jurídica portuguesa haja um elemento ponderoso de conexão, pessoal ou real». Ou seja, teria que se demonstrar uma dificuldade apreciável na propositura da ação na China e a conexão estreita entre o objeto de litígio e Portugal, o que neste caso existe, pois, os danos ocorreram em Portugal.

A segunda questão seria determinar a lei aplicável à causa e para esse efeito uma hipótese seria recorrer ao Regulamento (CE) no 864/2007 do Parlamento Europeu e do Conselho de 11 de julbo de 2007 relativo à lei aplicável às obrigaçôes extracontratuais (Roma II). Este Regulamento aplica-se às situaçôes referentes às obrigaçóes extracontratuais em matéria civil e comercial que impliquem um conflito de leis (art. 1o, oo 1). Porém, de acordo com a referida norma, o âmbito de aplicação do regulamento está circunscrito às matérias civis e comerciais, estando excluídas as matérias fiscais, aduaneiras e administrativas e a responsabilidade do Estado por atos e omissóes no exercício do poder público ${ }^{22}$. O Tribunal de Justiça da União Europeia (TJUE) considerou que não estamos perante matérias civis ou comerciais nos litígios que opõem uma entidade pública a uma entidade privada quando aquela atuou no exercício dos seus poderes de ius imperii ${ }^{23}$. Assim, estaremos perante uma matéria administrativa, se a entidade

22 Sobre o Regulamento Roma II e o seu âmbito de aplicação, v. Gonçalves, Anabela Susana de Sousa (2013). Da Responsabilidade Extracontratual em Direito Internacional Privado (pp. 226-271). Coimbra: Almedina; Anabela Susana de Sousa (2012). A responsabilidade civil extracontratual em direito internacional privado breve apresentação das regras gerais do Regulamento (CE) no 864/2007 (pp. 357-390). Scientia Iuridica, no 329, 2012.

23 V. neste sentido, TJUE, LTU Lufttransportunternebmen GmbH e Co. KG, Düsseldorf, e Eurocontrol, Bruxelas, Processo 29/76, de 14.10.1976, ECLI:EU:C:1976:137; idem, État néerlandais c. Reinhold Rüffer, Processo 814/79, de 16.12.1980, ECLI:EU:C:1980:291; idem, Volker Sonntag c. Hans Waidmann, Elisabeth Waidmann, Stefan Waidmann, Processo C-172/91, de 21.04.1993, ECLI:EU:C:1993:144; idem, Gemeente Steenbergen c. Luc Baten, Processo C-271/00, de 14.11.2002, ECLI:EU:C:2002:656, idem, Préservatrice foncière TIARD SA c. Staat der Nederlanden, Processo C-266/01, de 15.05.2003, ECLI:EU:C:2003:282; idem, Frabuil SA c. Assistalia SpA, Processo C-265/02, de 05.02.2004, ECLI:EU:C:2004:77; idem, Eirini Lechouritou e o. c. Dimosio tis Omospondiakis Dimokratias tis Germanias, Processo. C-292/05, de 15.02.2007, ECLI:EU:C:2007:102. 
pública em causa atuar no exercício de poderes de autoridade, e se existir uma ligação entre esse exercício e a causa objeto do litígio, o que parece ser o caso descrito. Logo, salvo se conseguirmos provar que em alguma situação a China não atuou com os seus poderes de ius imperii, estamos fora da aplicação do Regulamento Roma II e temos de recorrer às regras de conflitos do Código Civil, nomeadamente ao art. 45o, que estabelece uma regra de conflitos sobre responsabilidade civil extracontratual.

O art. 45 do Código Civil prevê, como elemento de conexão principal para as questôes de responsabilidade extracontratual, o lugar onde decorreu a principal atividade causadora do prejuízo, no seu no 1 . Todavia, a norma tem em conta as situações em que há uma cisão entre a conduta e as consequências da mesma. O no 2, do art. 45o, do Código Civil, permite a aplicação da lei do lugar onde se produziu o efeito lesivo em detrimento da lei do lugar da conduta, previsto no no 1 , da referida norma, desde que estejam reunidos dois requisitos cumulativos: se a lei do lugar da produção do efeito lesivo considerar o agente responsável, não o considerando a lei do lugar do comportamento; que o lesante devesse prever a produção do efeito lesivo naquele país. Se o dano, emergente do mesmo facto, se repercutir por vários países, o lugar do efeito lesivo será localizado em cada um destes territórios, sendo a lei de cada Estado competente para apreciar o efeito lesivo ocorrido no seu território ${ }^{24}$. Ora, se preenchidos os dois requisitos da norma, conseguiríamos aplicar a lei portuguesa aos danos ocorridos em Portugal.

Todavia, chegados a este ponto teríamos uma nova dificuldade, pois a China poderia invocar a imunidade de jurisdição. A imunidade de jurisdição dos Estados está prevista no art. 5o da Convenção das Naçôes Unidas sobre as Imunidades Jurisdicionais dos Estados e dos Seus Bens, onde se estabelece que um Estado goza de

\footnotetext{
24 Neste sentido também, Machado, João Baptista (1997). Liçôes de Direito Internacional Privado, 3 a Edição, Reimpressão (pp. 372-373). Coimbra: Almedina; Pinheiro, Luís de Lima (2015). Direito Internacional Privado, Direito de Conflitos, Parte Especial, Vol. II, 4aㅡ. Ed. (p. 486). Coimbra: Almedina; Pinheiro, Luís de Lima (2006). O direito aplicável à responsabilidade extracontratual na Internet. In Estudos de Direito Internacional Privado, Direito de Conflitos, Competência Internacional e Reconhecimento de Decisöes Estrangeiras (215-216). Coimbra: Almedina.
} 
imunidade de jurisdição junto dos tribunais de outro $\operatorname{Estado~}^{25}$. A imunidade de jurisdição de um Estado estrangeiro de acordo com o Direito Internacional Público parte do princípio de que «(...) um Estado soberano não pode ser demandado num tribunal de um outro Estado, traduzindo, assim, uma garantia que o Estado disfruta em relação a si próprio e aos seus bens e que impede que outros Estados exerçam jurisdição sobre os atos que realiza no exercício do seu poder soberano. Na consolidação da teoria relativa da imunidade de jurisdição do Estado, dela se consideram atualmente excluídos os atos de gestão (respeitantes a atos e contratos privados), apenas sendo considerados atos de imunidade de jurisdição dos estados os praticados sob a denominação de atos de império ${ }^{26}$. Há, todavia, exceçốes à imunidade de jurisdição no caso de danos causados a pessoas e bens, de acordo com o art. 12o da referida Convenção, mas olhando para a norma vislumbramos dificuldades na aplicação da mesma. Estabelece o art. 12ㅇ da referida Convenção das Naçôes Unidas que não pode ser invocada a imunidade de jurisdição em ação de indemnização «(...) em caso de morte ou de ofensa à integridade física de uma pessoa, ou em caso de dano ou perda de bens materiais causados por um ato ou omissão alegadamente atribuído ao Estado, se esse ato ou omissão ocorreu, no todo ou em parte, no território desse outro Estado e se o autor do ato ou omissão se encontrava nesse território no momento da prática do ato ou omissão». Ora, parece-nos que seria difícil provar que o autor do ato ou omissão se encontrava em território Português.

Ainda que ultrapassássemos a questão da imunidade de jurisdição, julgando os tribunais portugueses uma ação deste tipo, dando ganho de causa aos autores da ação e definindo uma indemnização a pagar pelo governo Chinês, levantar-se-ia a dificuldade de execução desta decisão e a tutela efetiva dos direitos em causa. Ora, a decisão teria de

25 Portugal ratificou esta convenção em 14 de setembro de 2006; a China, em 14 de setembro de 2005, apenas a assinou. Todavia, a doutrina considera que estamos perante direito consuetudinário internacional: Machado, Jónatas E. M. (2013). Direito Internacional, 4ae ed. (p. 242). Coimbra: Coimbra Editora; McGregor, Lorna (Abril 2006). State Immunity and Jus Cogens (pp. 437-446). International and Comparative Law Quarterly 55, no 2; Dickinson, Andrew (2009). State Immunity and State-Owned Enterprises (pp. 101-102). Business Law International 10 (2).

26 Tribunal da Relação de Coimbra, Processo 2079/15.1T8CBR.C1, Relatora Maria João Areias, de 10-052016. V. com mais desenvolvimento, Machado, Jónatas E. M. (2013). Direito Internacional, 4 à ed. (pp. 239 e segs). Coimbra: Coimbra Editora; McGregor, Lorna (Abril 2006). State Immunity and Jus Cogens (pp. 437446). International and Comparative Law Quarterly 55, № 2; 
ser executada na China e não existe qualquer acordo de cooperação judiciária entre a República Portuguesa e a República Popular da China, que o permita fazer. Existe a Convenção de Haia, de 20 de agosto de 1979, sobre o Reconbecimento e a Execução de Sentenças Estrangeiras em Matéria Civil e Comercial, que não teve grande sucesso, pois apenas tem cinco Estados Contratantes, entre eles Portugal, mas não a China. Existe ainda Convenção de Haia, de 2 de julbo de 2019 sobre o Reconhecimento e Execução de Sentenças Estrangeiras em Matéria Civil e Comercial, mas nem Portugal, nem a China são Estados contratantes. Além disso, existiria sempre a questão do conceito de matérias civis, parecendo-nos que dificilmente este conceito estaria preenchido no caso, pelas razóes supra enunciadas. Adicionalmente a China poderia sempre invocar a imunidade, agora, de execução, outra vertente da imunidade dos Estados, segundo a qual, ainda que com exceçôes, nenhuma decisão judicial pode ser tomada pelos tribunais ou autoridades de um Estado contra os ativos de outro Estado ${ }^{27}$.

\section{A INFLUÊNCIA DA COVID-19 SOBRE RELAÇÕES CONTRATUAIS INTERNACIONAIS}

Como já referimos, a COVID-19 obrigou os Estados a fechar fronteiras e a estabelecer medidas provisórias de limite a certas atividades. Em consequência, a circulação terrestre de mercadorias e pessoas foi reduzido, o transporte aéreo de mercadorias de pessoas e mercadorias também diminuiu, inclusive com algumas companhias aéreas a encerrar totalmente a sua atividade, num cenário que alguns meses antes não seria imaginável. Esta realidade teve efeitos em atrasos no cumprimento dos contratos internacionais, com atrasos na entrega de mercadorias, na prestação dos serviços, gerou impossibilidade do cumprimento das prestaçôes contratuais.

Esta realidade é suscetível de gerar outro tipo de responsabilidade civil, agora na vertente de responsabilidade contratual por não cumprimento pontual dos

27 Dickinson, Andrew (2009). State Immunity and State-Owned Enterprises (pp. 100-102). Business Law International 10 (2); Reinisch, August (2006). European Court Practice Concerning State Immunity from Enforcement Measures (pp. 803-835). European Journal of International Law 17. 
$\operatorname{contratos}^{28}$. Esta dificuldade no cumprimento dos contratos, potencia também pedidos de alteração dos contratos ou resolução dos contratos por alteração anormal das circunstâncias ${ }^{29}$. Isto significa, no plano do comércio internacional, um aumento dos litígios em relação aos contratos internacionais. Estarão em causa relações contratuais entre entes privados ou entre ente privados e públicos, desde que estes últimos estejam a agir despidos do seu poder de ius imperii, ou seja, como um ente privado.

Interessa, por isso, definir o regime jurídico aplicável aos contratos internacionais, sendo importante definir qual a jurisdição competente e a lei aplicável aos mesmos. Como há um conjunto de contratos que têm um regime especial, centrar-nos-emos nas regras gerais. Também por uma questão de vastidão da temática teremos que nos circunscrever à ordem jurídica da União Europeia.

\subsection{Tribunal competente}

Para determinar qual o tribunal competente para decidir os litígios emergentes dos contratos internacionais é necessário recorrer ao regulamento Bruxelas I bis, identificado supra. Este Regulamento tem um conjunto de regras referentes à competência internacional e um sistema de reconhecimento de decisóes estrangeiras tomadas ao abrigo deste Regulamento, assentando sobre o princípio do reconhecimento mútuo de decisóes e o princípio da confiança entre as autoridades judiciárias dos Estados-Membros ${ }^{30}$.

$28 \mathrm{Na}$ responsabilidade contratual, estamos perante a violação de uma obrigação em sentido técnico-jurídico, de um direito relativo, que resulta da vontade negocial das partes. V. sobre Leitão, Luís Manuel Teles de Menezes (2010). Direito das Obrigaçôes, Introdução, Da Constituição das Obrigaçôes, Vol. I, 9a Ed. (pp. 346-349). Coimbra: Almedina. Sobre a regra da pontualidade do cumprimento das obrigações, v. Varela, João de Matos Antunes (1999). Das Obrigaçôes em Geral, Vol. II, 7a Ed. (pp. 14-19). Coimbra: Almedina.

29 Sobre a possibilidade de modificação ou resolução do contrato por alteração das circunstâncias em que as partes fundaram a decisão de contratar, v. Varela, João de Matos Antunes (1999). Das Obrigaçôes em Geral, Vol. II, 7a Ed. (pp. 281-283). Coimbra: Almedina; Ascensão, José de Oliveira (Dezembro 2005). Onerosidade excessiva por "alteração das circunstâncias”. Revista da ordem dos Advogados, Ano 65 (vol. III); Leitão, Luís Manuel Teles de Menezes (2008). Direito das Obrigaçôes, Transmissão e Extinção das Obrigaçães, Não cumprimento e Garantias do Crédito, Vol. II, 6a Ed. (pp. 129-137). Coimbra: Almedina.

30 Sobre o significado destes princípios e da política de cooperação judiciária em matéria civil, v. Gonçalves, Anabela Susana de Sousa (2019). Cooperação Judiciária em Matéria Civil e Direito Internacional Privado (pp. 195-254). In Temas de Direito Internacional Privado e de Processo Civil Internacional. Porto: Librum Editora. 
O Regulamento Bruxelas I bis aplica-se a questões transnacionais, em matéria civil e comercial, estando excluídas as matérias fiscais, aduaneiras e administrativas (art. 1ㅇ). Estão também afastadas do seu âmbito de aplicação material as matérias elencadas no no 2, do art. 1: o estado, a capacidade das pessoas singulares; os regimes matrimoniais, os testamentos e as sucessões; as insolvências e medidas de recuperação de empresas; as questôes relacionadas com a segurança social; as situaçóes de arbitragem. $\mathrm{O}$ Regulamento não prejudica a aplicação de legislação da União Europeia que regule matérias idênticas (art. 67o), assim como a aplicação das convenções internacionais que versem sobre esta matéria e de que os Estados-Membros já sejam parte à data da entrada em vigor do regulamento (art. 71으, no 1).

As regras de competência internacional, previstas no regulamento, aplicam-se quando o réu tem domicílio no território de um Estado-Membro (art. 4o, oo 1 e no 2), independentemente da sua nacionalidade. Em princípio, as regras do Regulamento Bruxelas I bis que definem a competência internacional designam globalmente a ordem judiciária de um Estado, competindo às normas nacionais que repartem o poder jurisdicional de cada país, a definição material e territorial do tribunal que em concreto deve julgar a questão. Quando o réu tem domicílio num Estado terceiro, aplicam-se as regras de competência internacional de fonte interna (art. 5o, no 1), sem prejuízo do estabelecido nas disposiçóes legais previstas nas secções 2 a 7, do capítulo II do Regulamento Bruxelas I bis, que estabelecem uma exceção a esta norma. O sistema de reconhecimento automático estabelecido no regulamento é aplicado às decisóes proferidas nos Estados-Membros (art. 36ㅇ).

O Regulamento Bruxelas I bis aplica-se às açôes judiciais intentadas, aos instrumentos autênticos formalmente redigidos ou registados e às transações judiciais aprovadas ou celebradas a partir de 10 de janeiro de 2015 (art. 66으, ํo 1, e art. 81으).

O princípio fundamental do regulamento Bruxelas I é o princípio actor sequitur forum rei. O princípio do domicílio do réu está previsto no art. 4o, no 1, do Regulamento, existindo, nos termos do no 2 da mesma disposição legal, uma equiparação dos estrangeiros residentes num Estado-membro aos nacionais do mesmo Estado. Caso o requerido não tenha a sua residência habitual num Estado-membro, de acordo com o art. 6o de Bruxelas I bis, serão aplicadas as regras de competência de 
cada Estado-membro, salvaguardando-se o disposto no art. 18ㅇ, no 1, no art. 21으, no 2 , e dos arts. 240 e 25․

Para determinar o domicílio das pessoas singulares, o art. 62o remete para o direito interno dos Estados-membros. Todavia, no caso das pessoas coletivas, o art. 63o de Bruxelas I prevê uma noção autónoma de domicílio. De acordo com aquela norma, o domicílio da pessoa coletiva situa-se no local da sua sede social, da sua administração central ou do seu estabelecimento principal.

Juntamente com o fator atributivo de competência geral, o Regulamento Bruxelas I bis prevê normas de competência especial que fixam foros alternativos em relação à regra geral. Os fatores de competência especiais, previstos no art. 7o, foram pensados em função da proximidade do litígio com o tribunal ${ }^{31}$. Em matéria contratual, a ação pode ser proposta perante o tribunal do lugar onde foi ou deva ser cumprida a obrigação que fundamenta o pedido, nos termos do art. 7oㅡ, no 1, al. a), do referido Regulamento. A al. b) da mesma disposição legal, autonomamente, define o conceito de lugar do cumprimento da obrigação em certas situações. Desta forma, lugar do cumprimento nos contratos de compra e venda de bens será o lugar onde os bens foram ou devem ser entregues; nos contratos de prestação de serviços é o lugar onde os serviços foram ou devam ser prestados.

Existindo uma decisão, o Regulamento Bruxelas I bis prevê um sistema de reconhecimento automático de decisóes que proveem da União Europeia, nos termos do art. 36ํㅜㄹㅡ. Adicionalmente, o art. 39o do Regulamento Bruxelas I bis estabelece que uma decisão proferida num Estado-Membro, tendo aí força executória, poderá ser executada em outro Estado-Membro sem necessidade de uma declaração prévia de

31 Sobre os foros de competência alternativa, v. Gonçalves, Anabela Susana de Sousa (2019). A revisão do Regulamento Bruxelas I relativo á competência judiciária, ao reconhecimento e à execução de decisóes em matéria civil e comercial (pp. 129-149). In Temas de Direito Internacional Privado e de Processo Civil Internacional. Porto: Librum Editora; Mankowski, Peter (2016). Article 7 (pp. 121-369). In Ulrich Magnus e Peter Mankowski(Ed.), European Commentaries on Private International Law, Brussels I bis Regulation. Koln: OttoSchmidt. 32 Sobre este sistema de reconhecimento automático, v. Gonçalves, Anabela Susana de Sousa (2019). A revisão do Regulamento Bruxelas I relativo á competência judiciária, ao reconhecimento e à execução de decisóes em matéria civil e comercial (pp. 129-149). In Temas de Direito Internacional Privado e de Processo Civil Internacional. Porto: Librum Editora. 
exequibilidade. Logo, estas decisões devem ser tratadas como decisões nacionais do Estado-Membro onde se pretende a execução, pois, de acordo com o art. 41으, № 1, 2ª parte, $\ll[\mathrm{u}]$ ma decisão proferida num Estado-Membro requerido deve nele ser executada em condiçôes iguais às de uma decisão proferida nesse Estado-Membro, devendo aí ser reconhecida e executada mesmo que seja tomada em relação a pessoa não-domiciliada num Estado-Membro (considerando 27). A lei do Estado requerido rege a execução das decisóes provenientes de outros Estados-Membros (art. 41oㅡ, № 1, 1aㅡ parte).

De referir, que outra das formas de resolução das dos litígios privados internacionais é através do recurso à arbitragem privada internacional. A arbitragem é um modo de resolução alternativa de litígios que retira a resolução dos mesmos às jurisdições estaduais, estaduais e os entrega a árbitros e apresenta certas vantagens que a torna atrativa para resolver os litígios do comércio internacional. Entre outras vantagens, permite a escolha de decisores com especiais qualificaçóes na área do litígio; permite soluções mais flexíveis e ajustadas às circunstâncias do caso concreto; permite uma resolução mais rápida do litígio, também devido ao menor formalismo do processo; garante a confidencialidade; salvaguarda a neutralidade do foro arbitral ${ }^{33}$. Adicionalmente, verifica-se uma certa facilidade no reconhecimento e execução das decisões arbitrais estrangeiras, devido à existência da Convenção de Nova Iorque, de 1958, sobre o Reconbecimento e a Execução de Sentenças Arbitrais Estrangeiras. Ora, alguns tribunais arbitrais têm adotado procedimentos de arbitragem de urgência para a resolução de litígios surgidos em consequência da COVID-1934.

\subsection{A lei aplicável}

O regime jurídico geral dos contratos internacionais existente na União Europeia está previsto no Regulamento no 593/2008, de 17 de junbo de 2008, sobre a lei

\footnotetext{
33 Enunciando as vantagens da arbitragem transnacional, v. Pinheiro, Luís de Lima (2005). Arbitragem Transnacional, A Determinação do Estatuto da Arbitragem (pp. 24-26). Coimbra: Almedina; Barrocas; Manuel Pereira (2013). Manual de Arbitragem (pp. 563-564). Coimbra: Almedina.

34 É o caso do Centro de Arbitragem do Ilustre Colegio de Abogados de Madrid, que aprovou um procedimento de urgência para este tipo de litígios: http://www.cortearbitrajeicam.com/pdf/PROCEDIMIENTO\%20DE\%20ARBITRAJE\%20DE\%20URGENCIA.pdf, em 01.06.2020.
} 
aplicável às obrigaçôes contratuais (Roma I). O Regulamento Roma I versa sobre as obrigaçóes contratuais que envolvem um conflito de leis, ou seja, aquelas que estão em contacto com mais do que uma ordem jurídica em matéria civil e comercial, excluindo-se as questões fiscais, aduaneiras e administrativas (art. 1o, № 1). Estão excluídas, do âmbito material de Roma I, as obrigaçóes emergentes de negócios unilaterais e as matérias elencadas no seu art. 1으, no 2, nomeadamente: o estado e a capacidade das pessoas singulares [al. a)]; as obrigações resultantes de relações de família e relações equiparadas [al. b)]; as obrigaçóes decorrentes de regimes de bens e sucessóes [al. c)], entre outras elencadas nesta norma.

O regulamento Roma I tem um âmbito de aplicação universal, o que significa que a lei designada por força das normas nele previstas é aplicável, ainda que a ordem jurídica indicada não seja a de um Estado-Membro. Quanto ao seu âmbito de aplicação espacial, Roma I é aplicável a contratos celebrados a partir de 17 de dezembro de 2009 (art. 29o).

A lei determinada por força das normas de conflitos de Roma I regula as questôes enumeradas no art. 12을 nomeadamente: a interpretação do contrato [al. a)]; o cumprimento das obrigaçóes contratuais [al. b)]; as consequências do incumprimento total ou parcial das obrigações contratuais [al. c)]; as causas de extinção das obrigaçôes e a influência do tempo no exercício dos direitos, nomeadamente a prescrição e a caducidade [(al. d)]; entre outras matérias enumeradas de forma exemplificativa na norma.

O regulamento Roma I contém normas gerais aplicáveis à substância do contrato. Nesta categoria, enquadramos o art. 3o que é uma concretização do princípio da autonomia da vontade. Na ausência de escolha de lei, a norma que indica a lei supletivamente aplicável é o art. 4oㅜ que traduz o princípio de proximidade.

$\mathrm{O}$ art. 3o de Roma I prevê o princípio da autonomia da vontade, que se traduz na possibilidade de as partes escolherem a lei aplicável à relação jurídica contratual. A eleição de lei em Roma I obedece a certos requisitos de validade. Por exemplo, e entre outros requisitos, a escolha de lei pode resultar de uma declaração expressa ou tácita (art. 3o, no 1), pois a escolha de lei pode ser inferida das circunstâncias do caso concreto. As circunstâncias do caso concreto a ponderar podem resultar das negociaçôes 
que antecederam o contrato e da análise do próprio contrato, como por exemplo das referências a disposições legais ou a termos ou figuras jurídicas provenientes de certo ordenamento jurídico ${ }^{35}$.

Não existindo escolha de lei ou uma escolha válida de lei, nos termos do art. 4º no $1^{36}$ : ao contrato de compra e venda de mercadorias é aplicado a lei da residência habitual do vendedor [al. a)]; ao contrato de prestação de serviços é regulado pela lei da residência habitual do prestador de serviços [al. b)]; ao contrato que tenha por objecto um direito real sobre um bem imóvel ou o arrendamento de um bem imóvel será disciplinado pela lei do lugar da situação do imóvel [al. c)], entre outros. Como podemos observar, em algumas destas alíneas, como é o caso da al. a) e b), temos uma concretização do elemento de conexão residência habitual do devedor da prestação característica, que volta a aparecer no no 2 da norma. De acordo com o no 2, aos contratos que não sejam abarcados pela tipologia enunciada no no 1 do art. 4o ou que sejam abrangidos por mais do que umas das alíneas enunciadas será aplicável a lei da residência habitual do devedor da prestação característica do contrato.

A flexibilização da norma encontra-se no no 3, que estabelece uma cláusula de exceção que corrige a rigidez das normas previstas nos números anteriores em nome da justiça do caso concreto. Se resultar do conjunto das circunstâncias que o contrato tem uma conexão manifestamente mais estreita com uma lei diferente daquela indicada pelas conexões previstas no no 1 e no 2 da norma, será essa a lei aplicável. Os elementos

35 Para mais pormenores sobre o princípio da autonomia da vontade no regulamento Roma I, v. Gonçalves, Anabela Susana de Sousa (2019). O regime jurídico dos contratos internacionais no Regulamento Roma I (pp. 255-284). In Temas de Direito Internacional Privado e de Processo Civil Internacional. Porto: Librum Editora; Pinheiro, Luís de Lima (2008). O novo regulamento comunitário sobre a lei aplicável às obrigaçôes contratuais (Roma I) - uma introdução (pp. 594-595). Revista da Ordem dos Advogados 68; Mankowski, Peter (2017). Article 3 (pp. 87-263). In Ulrich Magnus e Peter Mankowski (Ed.), European Commentaries on Private International Law, Rome I Regulation. Koln: OttoSchmidt.

36 Para uma explicação mais detalhada do art. 4o do Regulamento Roma I, v. Gonçalves, Anabela Susana de Sousa (2019). O regime jurídico dos contratos internacionais no Regulamento Roma I (pp. 255-284). In Temas de Direito Internacional Privado e de Processo Civil Internacional. Porto: Librum Editora; Mangnus, Ulrich (2017). Article 4 (pp. 263-441). In Ulrich Magnus e Peter Mankowski (Ed.), European Commentaries on Private International Law, Rome I Regulation. Koln: OttoSchmidt. 
a ponderar dependem das circunstâncias do caso concreto e das ligaçóes que tenham com a situação ${ }^{37}$.

Por fim, não sendo possível determinar a lei aplicável em função das conexões estabelecidas no o 1 e no oㅡ 2, por exemplo no caso de contratos complexos e contratos em que as partes fornecem prestaçóes recíprocas, o no 4, do art. 4º, de Roma I, estabelece a aplicação da lei do país que tenha uma conexão mais estreita com o contrato. Para as situações individualizadas nesta norma, voltamos a uma cláusula geral de conexão mais estreita.

\section{CONCLUSÕES}

A globalização molda o nosso mundo e está presente no nosso quotidiano. A COVID-19 beneficiou dessa globalização para alcançar proporções pandémicas. Desta forma, gerou e vai continuar a gerar desafios jurídicos. Analisámos alguns desses desafios que se colocam às relações privadas internacionais, especificamente, a responsabilidade civil extracontratual em situações transnacionais por danos resultantes da COVID-19 e influência da COVID-19 sobre relaçôes contratuais internacionais.

Em relação à primeira questão, facilmente chegamos à conclusão que é difícil conseguir o ressarcimento deste tipo de danos de uma pessoa singular ou coletiva em relação a um Estado soberano. Por diversas vezes, tivemos de partir de cenários hipotéticos de difícil concretização. Existem muitas incertezas (inclusive em relação à natureza do vírus); enunciamos diversas dificuldades de prova; e a estes obstáculos junta-se o regime jurídico da imunidade dos Estados nas suas diversas vertentes. Completamente diferente é o panorama que encontramos nas relações entre sujeitos privados ou a agir numa veste privada. Como verificamos, em relação a possíveis distorções relativamente ao cumprimento dos contratos transnacionais de direito privado, resultantes da COVID-19, existe um conjunto de mecanismos com soluçôes para resolver os litígios que daí possam resultar.

37 Sobre o conceito de cláusula de exceção, v. Gonçalves, Anabela Susana de Sousa (2013). Da Responsabilidade Extracontratual em Direito Internacional Privado (pp. 422-464). Coimbra: Almedina. 